
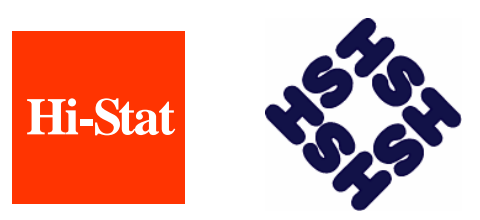

Discussion Paper Series

No.93

\title{
Foreign Exchange Intervention \\ and Monetary Policy in Japan, 2003-04
}

Rasmus Fatum and Michael M. Hutchison

June 2005

Hitotsubashi University Research Unit for Statistical Analysis in Social Sciences A 21st-Century COE Program

Institute of Economic Research Hitotsubashi University Kunitachi, Tokyo, 186-8603 Japan http://hi-stat.ier.hit-u.ac.jp/ 
Foreign Exchange Intervention and Monetary Policy in Japan, 2003-04*

Rasmus Fatum and Michael M. Hutchison 


\section{Introduction}

Japanese foreign exchange market intervention reached a new high in 2003, with the Bank of Japan (BOJ) selling 20.2 trillion yen (\$177 billion) in exchange for dollars - an amount surpassing that of any other country at any time. Massive dollar-support intervention operations continued in the first quarter of 2004, during which time the authorities sold another 14.8 trillion yen (\$139 billion) until March 17 at which time operations abruptly ended. ${ }^{1}$ Despite these efforts the yen exchange rate appreciated more than 14 percent during these 15 months, moving from 119 to 104 yen per dollar. (See Figure 1) Although Japan has been the most active amongst the larger industrial economies in its foreign-exchange-market operations during the past decade and more, the recent magnitude dwarfs all previous experience. (Intervention in 2002, for example, amounted to 4.0 trillion yen and operations only occurred in the second quarter).

Heavy intervention operations took place while conventional monetary policy instruments - interest rates and base-money growth - were seemingly ineffective in stopping the Japanese deflation. The overnight interbank rate (collateralized overnight call rate) was lowered to virtually zero in early 1999 and remained close to that level, never rising above 1/2 percent, for more than five years. ${ }^{2}$ (The rate was 0.001 percent during all of 2003 and the first nine months of 2004). The key monetary aggregate (M2+CDs) rose at only about 1.5-2.0 percent (annualized rate) during 2003 and the first half of 2004 despite the monetary base growing at an annualized rate of over 14 percent during this period. ${ }^{3}$ Japanese deflation continued in 2003-04 as the GDP deflator fell at an annual rate of about -2.5 percent. ${ }^{4}$ The Japanese price level has been declining by several measures since the mid-1990s. (See Figure 2)

This paper examines the rationale behind the massive increase in Japanese foreign exchange market intervention operations in 2003-04, and evaluates its effectiveness both in

\footnotetext{
${ }^{1}$ There was no intervention in the second quarter of 2004.

${ }^{2}$ The collateralized overnight interest rate (end of month) was lowered from 0.34 in December 1998 to 0.22 in January 1999 and 0.07 in February 1999. The rate was raised to the 0.20-25 range for a few months in late 2000 and early 2001, but again lowered to below 0.01 for most of 2001 and through September 2004.

${ }^{3}$ The monetary base (percent changes from a year earlier in average amounts outstanding) rose $25.7 \%$ in $2002,16.4 \%$ in 2003, $13.8 \%$ in 2004Q1 and 6.1\% in 2004Q2.

${ }^{4}$ Nominal GDP rose 0.3 percent in 2003 and at a similar annual rate in the first half of 2004. Real GDP growth, by contrast, indicated some recovery of the economy in 2003 and early 2004. (2003 real GDP growth was 3.2 percent).
} 
limiting yen exchange rate appreciation and influencing the direction of monetary policy. The two main questions addressed are: Was the intervention effective in slowing exchange rate appreciation compared to a counterfactual case with no intervention? And, has intervention on such a large scale authorized by the Ministry of Finance been able to directly influence liquidity creation or indirectly influence the stance of BOJ policy? The Ministry of Finance (MOF) determines intervention policy, but the BOJ determines whether to "sterilize" or offset the liquidity effect of selling yen for dollars in the market (and also acts as the agent for the MOF in carrying out foreign exchange operations). In principle, the MOF and the BOJ operate independently, but in practice may influence each other's policy stance. The sharp increase in the monetary base in 2003-04, shown in Figure 3, could be associated with the intensity and unprecedented magnitude of yen sales/dollar purchase foreign exchange intervention. One objective of our paper is to investigate the response of the BOJ to the shift in MOF policy.

The next section provides some institutional details on foreign exchange market intervention operations in Japan. Section 3 reviews recent evidence on the effectiveness of Japanese foreign exchange market intervention and presents some new results on this topic. Section 4 presents evidence on the extent to which intervention operations have been sterilized. Section 5 discusses the broader question of how the BOJ may have changed its policy direction to accommodate heavy foreign-currency intervention purchases in 2003-04. Section 6 concludes.

\section{Institutions}

The MOF in Japan has responsibility for foreign exchange market policy, ${ }^{5}$ though the BOJ acts as its agent in carrying out the market operations by using an account of the government called the Foreign Exchange Fund Special Account (FEFSA). ${ }^{6}$ This fund consists of foreign currency funds and yen funds. Financing Bills (FBs; short-term government bills) are issued by

\footnotetext{
${ }^{5}$ The Foreign Exchange and Foreign Trade Law stipulates that the "Minister of Finance shall endeavor to stabilize the external value of the yen through foreign exchange trading and other measures" (Article 7 , Section 3).

${ }^{6}$ Foreign exchange interventions are usually conducted in the Tokyo market. However, as most of the trading shifts to European markets after around 5:00 p.m. JST and then to the New York market, the BOJ requests foreign monetary authorities to conduct interventions on behalf of the Bank. The final decision to use this method is made by the MOF. The MOF also determines the details of the intervention including the amount, currency pair, and method of intervention (Bank of Japan, "Frequently Asked Questions: Outline of the Bank of Japan's Foreign Exchange Intervention Operations.” July 2000).
} 
the MOF to the market to obtain yen funds for the FEFSA, which in turn is used to purchase the foreign currency denominated assets. ${ }^{7}$ The financing bills (denominated in yen) are issued domestically to obtain yen funds before the foreign exchange purchase (yen sales), so in a technical sense the intervention is automatically sterilized. ${ }^{8}$ Financial bills are rolled over, when foreign currency denominated assets are maintained as foreign reserves. Sales of the foreign currency denominated assets result in reducing outstanding financial bills by redemption upon maturity (usually 3 months). There are a number of categories of FBs and legal limits on both the overall amount of FBs outstanding as well as the category of FBs used for financing foreign exchange purchases ("Foreign Exchange Fund Financing Bills”). This is shown in Table 1.

Japan has long been the most active participant in the foreign exchange market among the major industrial countries (Ito, 2003; Fatum and Hutchison, 2006). However, a sharp departure with past policy - in terms of magnitude and frequency - started when Japan's interventions became much more active starting on January 15, 2003 and continuing for more than a year until March 16, 2004 (Ito, 2004). During these four quarters, the MOF sold 35 trillion yen to purchase dollars. The first quarter of 2004 was particularly intense, shown in Figure 1, as the MOF sold a total of 14.8 trillion yen. In line with the increase in foreign exchange intervention intensity, outstanding foreign exchange bills (FBs) rose by 75\% or 36.4 trillion yen between March 2002 and March 2004. Similarly, foreign currency reserves held by Japan during this period increased by almost 80 percent - from $\$ 451.5$ billion at year-end 2002 to $\$ 806.0$ billion by the end of March 2004. Table 2 shows the rapid accumulation of foreign reserves in Japan during this period. The current level of foreign currency reserves of over $\$ 800$ billion is the largest recorded in the postwar period in either real or nominal terms in Japan or elsewhere in the world. Foreign exchange reserves in Japan in early 2004 comprised about one-third of the world's foreign exchange reserves.

Surprisingly, there was no official announcement of a policy change in January 2003 when the scale and frequency of intervention increased. A dramatic departure in policy was

\footnotetext{
${ }^{7}$ There are five types of Financial Bills (FBs), each of which is associated with some Special Account or the General Account of the Government of Japan's budget. The FBs associated with the Foreign Exchange Funds Special Account accounts for the largest share in the amount of outstanding FBs, usually more than 90 percent.

${ }^{8}$ See Ito (2002) for a detailed discussion.
} 
evident because there had been no intervention in the market since June 28, 2002. Nor was the move associated with a change in either the Finance Minister or the Governor of the BOJ at the time. (BOJ Governor Fukui was appointed in March 2003 and Finance Minister Sadakazu Tanigaki took office in September 2003.) And Japan's massive intervention in the foreign exchange market abruptly ended on 16 March 2004. Again there was no official statement by the government explaining why intervention operations were stopped so suddenly after more than a year of heavy intervention and the largest accumulation of foreign exchange reserves ever recorded. Rather, Minister of Finance Tanigaki stated in late March that the MOF intervention policy had not changed (The Asian Wall Street Journal, 30 March 2004). ${ }^{9}$

Ito (2004) points out that the interventions began (January 15) just a day after a new Vice Minister for International Affairs, Mr. Mizoguchi, took office. He also points out that the intervention was initially "stealth" intervention in the sense that the large-scale intervention of the January-March 2003 was not disclosed until May of that year.

\section{Has Intervention Been Effective in Japan?}

\subsection{Recent Studies on Effectiveness of BOJ Intervention}

Several recent studies of intervention find support for the effectiveness of intervention operations (for surveys of the literature see Dominguez, 2003; Dominguez and Frankel, 1993; Edison, 1993; and Sarno and Taylor, 2001). In the context of this paper, recent studies by Dominguez (2003), Ito (2003, 2004) and Fatum and Hutchison $(2004,2006)$ are of particular interest as all investigate official BOJ intervention data at daily frequencies, employ very different methodologies in order to do so, yet arrive at quite similar conclusions. ${ }^{10}$

Table 3 provides a brief overview of these studies' results on the effectiveness of BOJ intervention. In order to assess the impact of BOJ intervention over the January 1991 through June 2002 time-period, Dominguez (2003) analyzed the full sample as well as five separate subsamples. Focusing first on short-term effects of intervention, she shows, for the full sample, that

\footnotetext{
${ }^{9}$ The issue of massive foreign exchange market intervention was not even a topic addressed in the "Japan: Selected Issues” of the IMF Country Report No. 03/282 on Japan published in September 2003.

${ }^{10}$ See, for example, Galati, Melick and Micu (forthcoming) and Truman (2003) for studies questioning the effectiveness of intervention.
} 
intervention had significant effects in the appropriate direction on 4-hour exchange rate returns, while short-term effects on 8-hour exchange rate returns were insignificant. When addressing the issue of success during intervention, Dominguez (2003) found that for only two of the five episodes was it the case that the JPY/USD exchange rate moved in the appropriate direction over the period in which the intervention took place. Turning the focus to long-term effects, she found evidence that the JPY/USD exchange rate moved in the appropriate direction within three months of the last intervention operation of the episode (or longer) for all five sub-samples.

Fatum and Hutchison (2006) note that intervention in the JPY/USD exchange rate tended to come in clusters interspaced by prolonged periods of no intervention, and suggested an event study as a particularly fitting methodology for analyzing the BOJ intervention data. Defining an event as a period of days with official intervention in the JPY/USD exchange rate in one direction (in terms of purchases or sales), conducted by the BOJ, the U.S. Federal Reserve, or both, and possibly including five consecutive days of no intervention, they identified 43 intervention events over the 10-year (April 1991 to March 2001) period. Applying three different criteria for what may constitute effectiveness, Fatum and Hutchison found strong evidence that intervention systematically affected the exchange rate in the short-run. This main result held even when intervention was not associated with (same-day) interest rate changes, and regardless of whether or not intervention was "secret" or reported in the news-wires. They also found that intervention was most likely to succeed when it was coordinated and large scale (amounts over USD 1 billion).

Using a time-series framework with GARCH(1,1) specifications for addressing the issue of effectiveness, Ito (2003) investigated the April 1991 through March 2001 time-period. He showed that intervention was more frequent and more predictable during the April 1991 to 20 June 1995 period, and found that intervention was ineffective during this sub-sample. In fact, his results for this sub-sample suggested that intervention was systematically associated with exchange rate changes in the opposite direction of what was presumably intended (i.e., BOJ purchases of USD were associated with USD depreciations). For the second sub-sample, 21 June 1995 through March 2001, Ito (2003) found that intervention was effective (i.e., the estimated coefficients were significant and of the "correct" sign). Additionally, he showed that coordinated 
intervention (by both the Fed and the BOJ) was more effective than unilateral intervention (BOJ only).

More recently, Ito (2004) investigated BOJ intervention during the January 2003 through March 2004 time-period. Using a time-series methodology consistent with Ito (2003), he found that the 2003-2004 interventions were effective, but his coefficient estimates suggested that the degree of impact declined to the level of $1 / 5$ when compared to intervention carried out during the 1995-2003 sub-sample. Additionally, he found initial interventions (i.e., intervention that was not preceded by intervention for five days) to be more effective than subsequent interventions (i.e., intervention following days of intervention).

\subsection{The Event Study/Matching Approach}

Fatum and Hutchison (2004) have introduced the "matching-methods" methodology to the intervention literature in order to investigate the effectiveness of BOJ intervention while at the same time addressing the issue of sample selection. Fundamentally, studies of central bank intervention - where the effectiveness of intervention is assessed based on contemporaneous or subsequent exchange rate movements - are potentially contaminated by sample selection bias. Intervention typically occurs during periods of abnormal exchange rate movements and not when normal exchange rate market conditions prevail. Fatum and Hutchison observe intervention and its effects during a select sample period (typically of market turmoil), but not during more normal episodes. Hence, the value of a matching methodology is to "match up" economic circumstances that lead to intervention (similar probabilities of intervention), and differ only in that in one case intervention occurred and in another it did not. Better estimates of the effectiveness of intervention may be obtained by using this methodology.

The analysis of Fatum and Hutchison (2004) consists of two parts. In the first part, logit models of the BOJ's decision to intervene are estimated. From these logit model estimates, the probability of intervention (a propensity score) for each day in the sample is derived. The sample is then split into a sub-sample of days when intervention actually occurred and a sub-sample of days when no intervention occurred. Regardless of whether or not intervention actually did occur on a given day, there is a uniquely defined intervention probability associated with each day in 
both sub-samples as well as a realized (day-to-day) change in the JPY/USD exchange rate. In the second part, a matching algorithm - the so-called "nearest neighbor" algorithm where each intervention observation is matched with the no-intervention observation that has the "nearest" propensity score - is implemented and the average effect of intervention on exchange rates (using each algorithm separately) is examined, using difference-in-means tests.

The main findings of Fatum and Hutchison (2004) are summarized in Table 3, and the specific matching methods results are displayed in Table 4. Analyzing the most recent 5 years of BOJ intervention data, the study found that intervention was effective during the 1999 to 2002 sub-sample, while intervention had no significant impact on the JPY/USD exchange rate during the 2003 sub-sample. For the first quarter of 2004, the study found that intervention was systematically associated with exchange rates moving in the opposite direction of what was intended by the intervening authority, suggesting that intervention may even be counterproductive rather than merely ineffective.

Fatum and Hutchison (2004) note that the BOJ's intervention frequencies across the January 1999 through March 2004 time-period have changed dramatically. Specifically, the BOJ intervened on an average of 3\% of business days over the 1999 to 2002 period during which the study found support for effectiveness, compared to an intervention frequency of $35 \%$ of business days over the 2003 period during which the study found no significant impact of intervention. In contrast, the intervention frequency rose to $85 \%$ over the first quarter of 2004 , the sub-sample during which intervention appeared to be significantly counterproductive.

Table 4 shows the specifics of the matching methods results and, in particular, that the significant results found in the 1999 to 2002 and the first quarter of 2004 sub-samples both stemmed primarily from the impact of single-day intervention operations (i.e. intervention operations that "stand alone" in the sense that intervention on a given day did immediately succeed intervention on the previous day and was not succeeded by intervention on the following day) and first-day intervention operations (i.e., the first day of several consecutive days of intervention).

The described study found intervention to be effective during a time-period of infrequent interventions while it found intervention to be ineffective or even counterproductive during time- 
periods of very frequent intervention. Interestingly, these findings seem consistent with the timeseries based study by Ito (2003), who shows that intervention during the April 1991 to 20 June 1995 time-period characterized by frequent interventions was ineffective while intervention during the 21 June 1995 to March 2001 time-period characterized by relatively infrequent interventions was effective. Additionally, the findings of Fatum and Hutchison (2004) with respect to the first sub-sample of their analysis - January 1999 through December 2002 - are in line with Dominguez (2003), who finds evidence of significant effects in the appropriate direction on both 4- and 8-hour exchange rate returns as well as 48-hour persistence when focusing on the two most recent episodes (January 1999-April 2000 and September 2001-June 2002) in her dataset. However, Ito (2004) found that BOJ intervention was effective over the (full) January 2003 through March 2004 time-period, while the results in Fatum and Hutchison (2004) suggest that, after taking into account the issue of sample selection and based on investigations of 2003 and the first quarter of 2004 separately, the impact of intervention was insignificant during 2003 and, furthermore, significant but of the "wrong" sign during the first quarter of 2004.

\section{Was Intervention Sterilized? The BOJ Response to Intervention Operations}

Fatum and Hutchison (2004) and Ito (2004) find that intervention operations were less successful in 2003-04 period than in the late 1990s (e.g. evidence presented by Ito, 2003; Fatum and Hutchison, 2006). Moreover, Fatum and Hutchison found the interventions of early 2004 to have been ineffective, and argue an association with the frequency and associated predictability of the operations compared to previous periods.

Is the reduced effectiveness of intervention over the 2003-04 period, compared with the 1995-2002 period, related to the degree of sterilization? Unsterilized intervention can influence exchange rates in the same way as monetary policy by inducing changes in the monetary base and, in turn, broader monetary aggregates, interest rates and market expectations. By contrast, the transmission mechanism by which sterilized intervention may systematically influence exchange rates is less clear and somewhat controversial in the literature. ${ }^{11}$

\footnotetext{
${ }^{11}$ See Sarno and Taylor (2001) for a recent survey of the theoretical and empirical literature and Dominguez (2003) for a description and analysis of the foreign exchange market intervention in the 1990s.
} 
Intervention operations carried out by the BOJ, on behalf of the MOF, are generally regarded as automatically sterilized since the MOF first raises the necessary funds for foreign exchange purchases by selling yen-denominated bills to the market (Ito, 2003). Specifically, in the case of intervention aimed at dampening or reversing JPY appreciations, JPY-denominated financing bills are issued to the market and the proceedings are, in turn, used to purchase foreign currency denominated assets in the intervention operations.

However, the BOJ may still respond to dollar purchase/yen sale intervention operations undertaken by its own foreign exchange dealers in the Foreign Exchange Division of the Financial Markets Department - by increasing the money supply. In this context, the question arises as to the appropriate indicator to consider in measuring the BOJ's immediate (daily or weekly) and longer-term (monthly or quarterly) response to interventions directed by the MOF.

Our analysis is focused on the 2003-04 period during which time financial institutions' deposits in current accounts held with the BOJ (“current account balances” or CABs) were the primary operational target of Japanese monetary policy. This is the measure we employ in our analysis of daily sterilization operations. We complement the current-account-balance measure with the monetary base in the analysis of monthly and quarterly interactions between intervention and monetary policy.

\subsection{Short-run Sterilization}

In order to investigate whether BOJ interventions are systematically affecting the current account balance on a day-to-day basis, we carry out a time-series analysis of daily data. Specifically, we regress the first-difference of the BOJ current account balance ( $\triangle C A B)$ on a constant $(\alpha)$, the contemporaneous and five (three) lags of intervention (INT), and an error term $(\varepsilon)$, as captured by the following equation:

(1) $\Delta C A B_{t}=\alpha+\sum_{i=0}^{5} \beta_{i} I N T_{t-i}+\varepsilon_{t}$

Since the funds required for carrying out interventions are raised by the MOF prior to the intervention operations taking place, complete sterilization is consistent with no $\mathrm{CAB}$ response to intervention. In other words, if intervention was indeed sterilized, we should expect the cumulative effect of intervention on the CAB to equal zero. 
The results of the estimations are reported in Table 5. The first two columns show the results based on the January to December 2003 sub-sample, with the regression reported in the first (second) column incorporating five (three) lags of intervention. None of the explanatory variables are statistically significant and, furthermore, the F-test of Sum Equals Zero (Wald-test) shows that the hypothesis of the sum of the estimated coefficients being equal to zero cannot be rejected. The last two columns show the results based on the January to March 2004 sub-sample, with the regression reported in the first (second) column incorporating five (three) lags of intervention. Although the first through third lags are significant in both regressions, the signs of the significant coefficients alternate from negative to positive to negative, and it appears that these effects on the CAB cancel each other out. This is confirmed by the F-test of Sum Equals Zero, which for both regressions suggests that the cumulative effect of intervention on the CAB is zero.

In sum, this clearly suggests that intervention activity does not explain changes in the BOJ's CAB and, as noted by Spiegel (2003), there is little correlation between these two variables at a daily frequency.

\subsection{Is the BOJ Responding to the Intervention Policy Set by the MOF?}

The rapid increase in the Japanese base money at a time when the MOF/BOJ has undertaken prolonged large-scale intervention in support of the USD may suggest that the recent interventions are unsterilized over the course of months and quarters. For example, Spiegel (2003), in discussing a Nikkei Financial Daily article, notes that "the total value of interventions from the beginning of 2003 until the end of August matched almost exactly the increase in the BOJ's current account balance over that period, suggesting that the BOJ left the funds associated with its intervention activity in the market”. Although we do not find a connection between intervention and the current account at the daily frequency, it is entirely possible that the two variables are highly correlated at lower frequencies, such as monthly or quarterly data.

Table 6, part A, and Figure 4 show the monthly totals of intervention juxtaposed against the monthly changes in the current account. Although both series are obviously trending upwards over the time period under study, the two series do not appear highly correlated on a month-to- 
month basis, with (monthly) correlation coefficients for the full and the 2003 samples of 0.34 and 0.28 , respectively.

Table 6, part B, shows stepwise-accumulated intervention totals next to stepwise accumulated current account changes. The displayed numbers confirm that the total value of interventions from the beginning of 2003 until the end of August matched the increase in the BOJ's CAB over that same period. However, it also shows that this was in fact the only period over which accumulation of the two series would produce matching numbers, suggesting that the observed one-to-one correspondence between intervention and $\mathrm{CAB}$ is a random occurrence specifically pertaining to the January to August 2003 accumulation period.

5. Was BOJ Policy More Expansionary Due to MOF Intervention Decisions in 2003-04?

5.1 Purchases of Foreign Assets by the BOJ and Repurchase Agreements with the MOF

The analysis in the previous section does not find any formal statistical evidence that the BOJ responded to daily intervention operations by increasing bank reserves (current-account balances). The linkage between intervention and current-account balances over longer periods was also tenuous during the sample period.

Intervention appears to have been sterilized in a technical sense since the MOF raised yen-funds by selling bills to the private sector, and the BOJ did not respond by increasing base money. The main exception to this was in early 2004 when the MOF financed intervention operations by entering into a repurchase agreement of FEFSA-held U.S. Treasury Notes with the BOJ. The BOJ annual report summarized the operation: "On December 26, 2003, the Bank agreed with the MOF that the Bank would purchase up to 10 trillion yen of FEFSA-held U.S. Treasury Notes with a resale agreement, as an indispensable but temporary means of financing until other means became available to the FEFSA, when the MOF recognized that the FEFSA has virtually exhausted its room for short-term borrowing due to its budgetary limitations.” (Bank of Japan Annual Review 2004, p. 67). ${ }^{12}$

This request and operation are highly unusual (not used since 1987) and would have resulted in unsterilized intervention (i.e., an increase in the monetary base) had the BOJ not

\footnotetext{
${ }^{12}$ The U.S. Treasury Notes were sold by the Bank of Japan back to the FEFSA by the end of June (as per the terms of the original agreement).
} 
undertaken offsetting action. The Governor of the BOJ, in testimony to the Diet, stated that operation was "exceptional and temporary," and that he hoped it would not be repeated. (Reuters News, 22 March 2004; semi-annual testimony before parliament). The main motivation for this move was that the legal ceiling on borrowing in the foreign exchange account had almost been reached (The Japan Times, 10 January 2004). Increases in the limit have since been approved by the Diet (Table 1), and the repurchase of the securities was completed on schedule later in the year.

\subsection{Where Is Base-Money Expansion Coming From?}

The BOJ is purchasing assets other than foreign currency in its expansion of the monetary base. BOJ holdings of government securities increased from 83.6 trillion yen at end-September 2002 to 94.1 trillion yen at end-September 2004. This 10.5 trillion yen rise represents about half the increase in the monetary base during the period. By contrast, BOJ holdings of foreign currency assets were virtually unchanged during the past two years: 4.1 trillion yen at endSeptember 2002 compared to 4.4 trillion yen at end-September 2004. ${ }^{13}$

Clearly, the BOJ expanded its balance sheet using instruments beyond traditional shortterm government debt. This was likely a good strategy because short-term government securities are "near money" in an environment of zero short-term interest rates and would not effectively provide monetary stimulus, i.e., amounting to purchases of "near money" (short-term government securities) from the private sector to create base money.

\subsection{Base Money and Intervention: Statistical Analysis}

The BOJ, however, may have responded to exceptionally large interventions by the MOF in 2003-04 by pursuing a more expansionary policy than it otherwise would have done - not by purchasing foreign-currency denominated assets from the FEFSA but by purchasing other assets and timing purchases such that they did not coincide closely with daily or weekly intervention operations. Ito (2004, p. 13) points out, for example, that the increase in the monetary base and cumulative intervention from March 2001 to March 2003 were almost identical, but that it is not

\footnotetext{
${ }^{13}$ The amount of foreign currency assets was 4.2 trillion yen at end-September 2003.
} 
clear whether the BOJ and MOF were coordinating policy or whether it was a coincidence of two independent decisions.

\section{Comparative episodes}

It is not clear why January 2001- March 2004 is an appropriate base to make a comparison since during the first two years of the period the MOF authorized intervention on only 7 days in late September 2001 and 7 days in late May and June 2002. There clearly was no link between cumulative intervention and base-money increase in 2001-02, and a distinct shift in intervention policy occurred in early 2003. January 2001 is not a random date, but the only starting point that would put the two series (monetary-base increase and cumulative intervention) coincident in March 2004. Moreover, Table 6 shows that cumulated intervention from January 2003 to March 2004 - the period of heavy intervention by the BOJ signaling a change in policy was about 35 trillion yen while the increase in the monetary base was less than half of that amount (16.8 trillion yen).

We look at previous episodes of heavy intervention in order to assess whether BOJ policy during 2003-04 was unusual, i.e., whether recent policy appears more responsive or coordinated with intervention operations compared to previous experience. Figure 5 compares the cumulative intervention and base-money increase during the three episodes since the early 1990s of intense and systemic intervention operations: April 1993-March 1996 (base month: March 1993), January 1999-June 2000 (base month: December 1998), and the recent episode (January 2003-March 2004; base month: December 2002). The "base month” is the starting point whereby both series are set to zero.

While the base-money increase is less than half of cumulative foreign exchange intervention during the most recent episode, this pattern is not unusual. In all three episodes cumulative intervention significantly exceeded the increase in base money - by 56 percent during the 1993-96 episode, 26 percent during the 1999-2000 episode, and 116 percent during the 200304 episode. There appears less linkage between intervention and base money during the 2003-04 episode than previously, and no indication of coordination between the MOF and BOJ centering on intervention policy. 
Does intervention predict money growth?

To directly address the issue of whether MOF intervention operations have influenced BOJ base-money increases, we consider some simple base-money equation estimates and forecasts. First, we estimate a model that explains base money (changes) by 12 lags of base money, the call-money interest rate and the magnitude of intervention. Estimating the equation over 1991:12 - 2004:09 (with monthly data), the coefficient on intervention is positive but insignificantly different from zero. Estimating the equation over a more recent period, 2001:01 to 2004:09, gives a negative but insignificant coefficient on intervention. These results suggest that intervention operations were not a determinant of money base growth in Japan over these periods.

Second, we consider the structural stability of the equation in an attempt to detect whether a regime change in base-money growth is linked with the timing of massive interventions starting in 2003. Recursive residuals (with 2 standard errors) are shown in Figure 6. This stability test finds instability, but beginning in 2000 or 2001 not in 2003. Using the 1991:12 - 2004:09 sample period, a formal Chow test of structural stability in 2001:01 is rejected at the 1 percent level (F-Statistics is 2.15), but stability is not rejected at the 2003:01 breakpoint (F Statistic is 0.902). In the recent sample period where there was a structural break from past experience (2001:01-2004:09), there is no evidence of a structural break in 2003:01 - the Chow test Fstatistic is 0.34 - at the time of large intervention operations.

Third, we use the model to calculate two out-of-sample forecasts of base-money growth. The first estimates the model to the point where the recursive residuals and the Chow tested indicated a breakpoint: 1991:12-2000:12 and (dynamically) forecasts base-money growth for the 2001:01-2004:09 period. (This is a dynamic forecast in that lagged forecast values of money growth are used as explanatory variables beyond the estimation sample. Actual values of intervention and interest rates are used in the forecast interval). The forecast values, shown in figure 7, greatly underestimate the actual value of base money. Clearly, a fundamental policy shift - a move toward base-money expansion - is evident in early 2001.

By contrast, when the model is estimated from 2001:01-2002:12 - a stable period according to the structural break tests - the forecast value of base money is very close to actual base money (Figure 8) when it is forecast out-of-sample over the heavy intervention period (2003:01-2004:09). 
By September 2004, base money is only slightly lower than the forecast value. In sum, there is no evidence that the large intervention operations starting in 2003 led to more rapid base-money creation by the BOJ. Rather, the shift in BOJ policy towards more rapid base-money expansion occurred in early 2001 - two years before the shift in MOF intervention policy.

\section{Conclusions}

This paper has examined the rationale behind the massive increase in Japanese foreign exchange market intervention operations in 2003-04, and has evaluated its effectiveness both in limiting yen exchange rate appreciation and influencing the direction of monetary policy.

We find intervention is somewhat effective over short periods of time (several days), but less so in the recent period of very heavy intervention compared to previous episodes. We attribute this to the predictability of intervention in 2003, and especially 2004 (due in turn to the intensity and frequency of operations), which in turn allows the market to anticipate these operations and accordingly formulates expectations into the level of the exchange rate.

Limited effectiveness of intervention in the most recent period, however, may also be associated with a high degree of sterilization. We consider institutional factors (how intervention is financed) and also statistically investigate whether current-account balances set by the BOJ are influenced by daily intervention operations. This analysis suggests that from a technical perspective the BOJ has not allowed MOF intervention decisions to influence the day-to-day conduct of monetary policy.

In addition, we do not find statistical evidence that the BOJ has changed the direction of policy in response to large intervention operations in 2003-04. Base-money growth was very rapid during this period, but it was not associated with foreign asset purchases by the BOJ. Moreover, cumulative foreign currency purchases by the MOF were more than twice as large as the increase in base money. Earlier episodes of intensive intervention were much more closely matched by base-money increases than in the 2003-04 period.

We also considered structural breaks in the money-base equation and out-of-sample forecasts. We found that a structural break towards more expansionary base-money expansion occurred in 2001, but not in 2003 when the shift in intervention policy occurred. Reflecting this 
structural break point, out-of-sample forecasts starting in 2001 (with the equation estimated through 2000) greatly underestimated base-money growth over the 2001-04 period. However, out-of-sample forecasts starting in 2003 - with the equation estimated through 2002 and hence incorporating the structural break and expansionary base-money growth that had already been underway for two years - tracked observed base-money growth very closely.

We found no evidence that the BOJ responded to intervention actions by the MOF in 2002-04 by increasing base money at a rate faster than it otherwise would have done. The BOJ on its own was attempting to stimulate the economy in 2001-04 through rapid base money growth, but this was apparently not influenced by the "activist” intervention policy of the MOF during the latter part of this period. 


\section{References}

Bank of Japan (2004), Annual Review 2004.

Dominguez, K. M. (2003), 'Foreign Exchange Intervention: Did It Work in the 1990s?' in F. Bergsten and J. Williamson (eds.), Dollar Overvaluation and the World Economy (Washington DC: Institute for International Economics).

Dominguez, K. M. and J. A. Frankel (1993), Does Foreign Exchange Intervention Work? (Washington, DC: Institute for International Economics).

Edison, H. J. (1993), 'The Effectiveness of Central Bank Intervention: A Survey of Post 1982 Literature’, Essays in International Finance (Princeton: Princeton University Press).

Fatum, R. and M. M. Hutchison (2006), 'Effectiveness of Official Daily Foreign Exchange Market Intervention Operations in Japan’, NBER Working Paper No. 9648, Journal of International Money and Finance (forthcoming).

Fatum, R. and M. M. Hutchison (2004), 'Sample Selection and Foreign Exchange Market Intervention: A Matching Methods Investigation of Official Bank of Japan Intervention', mimeo.

Galati, G.; W. Melick and M. Micu (2003), 'Foreign Exchange Market Intervention and Expectations: An Empirical Study of the Yen/Dollar Exchange Rate', Journal of International Money and Finance (forthcoming).

International Monetary Fund (2003), Japan Country Report 03/282, September (mimeo).

Ito, T. (2003), 'Is Foreign Exchange Intervention Effective?: The Japanese Experience in the 1990s’ in P. Mitzen (ed.), Monetary History, Exchange Rates and Financial Markets, Essays in Honour of Charles Goodhart, Vol. 2, Edward Elgar, UK, and NBER Working Paper No. 8914.

Ito, T. (2004), 'The Yen and the Japanese Economy, 2004' (Washington DC: Institute for International Economics).

Sarno, L. and M. P. Taylor (2001), 'Official Intervention in the Foreign Exchange Markets: Is It Effective and, If So, How Does It Work?', Journal of Economic Literature 34, 839-68.

Spiegel, M. (2003), 'Japanese Foreign Exchange Intervention', FRBSF Economic Letter No. 2003-36. 
Truman, E. M. (2003): 'The Limits of Exchange Market Intervention’ in C. F. Bergsten and J. Williamson (eds.), Dollar Overvaluation and the World Economy (Washington DC: Institute for International Economics). 
Table 1. Financing Bills in Japan (Trillion Yen)

\begin{tabular}{lcc}
\hline & Total Financing Bills & $\begin{array}{l}\text { Foreign Exchange } \\
\text { Fund Financing Bills }\end{array}$ \\
\hline March 2000 (FY1999) & 44.2 & 39.6 \\
March 2001 (FY2000) & 47.6 & 43.8 \\
March 2002 (FY2001) & 49.6 & 48.6 \\
March 2003 (FY2002) & 57.5 & 56.6 \\
March 2004 (FY2003) & 86.1 & 85.0 \\
& & \\
FY 2003 Legal Limit of Issuance & 141.0 & 100.0 \\
FY 2004 Legal Limit of Issuance & 171.0 & 140.0 \\
\hline
\end{tabular}

Source: Ministry of Finance.

Table 2. Foreign Exchange Reserves in Japan (Billions of USD)

\begin{tabular}{|c|c|c|}
\hline Date (End of Period) & Official Reserve Assets & Foreign Currency Reserves \\
\hline & & \\
\hline 2002 Q1 & 401.5 & 385.7 \\
\hline 2002 Q2 & 446.2 & 428.9 \\
\hline 2002 Q3 & 460.7 & 443.1 \\
\hline 2002 Q4 & 469.7 & 451.5 \\
\hline 2003 Q1 & 496.2 & 477.8 \\
\hline 2003 Q2 & 545.6 & 526.6 \\
\hline 2003 Q3 & 604.9 & 584.1 \\
\hline 2003 Q4 & 673.5 & 652.8 \\
\hline 2004 Q1 & 826.6 & 806.0 \\
\hline 2004 Q2 & 818.0 & 798.6 \\
\hline
\end{tabular}

Source: Ministry of Finance. 
Table 3. Effectiveness of Bank of Japan Intervention: Five Recent Studies

\begin{tabular}{|c|c|c|c|}
\hline Study & Time-period & Methodology & Key Findings \\
\hline Dominguez (2003) & $\begin{array}{l}\text { January } 1991 \text { - } \\
\text { June } 2002\end{array}$ & $\begin{array}{l}\text { Event-study and } \\
\text { time-series }\end{array}$ & $\begin{array}{l}\text { - Short-term effects in "right" direction } \\
\text { - 48-hour persistence in } 3 \text { of } 5 \text { episodes } \\
\text { - Not effective over duration of episode } \\
\text { - Effective within } 3 \text { months of last } \\
\text { intervention operation }\end{array}$ \\
\hline $\begin{array}{l}\text { Fatum and } \\
\text { Hutchison (2002) }\end{array}$ & $\begin{array}{l}\text { April } 1991- \\
\text { March } 2001\end{array}$ & Event study & $\begin{array}{l}\text { - Short-term effectiveness (less than } \\
\text { one month) } \\
\text { - Effectiveness whether or not } \\
\text { supported by interest rate changes } \\
\text { - Effectiveness whether secret or } \\
\text { reported in newswires } \\
\text { - Most likely to succeed when } \\
\text { coordinated (both Fed and BOJ) and } \\
\text { large scale }\end{array}$ \\
\hline $\begin{array}{l}\text { Fatum and } \\
\text { Hutchison (2004) }\end{array}$ & $\begin{array}{l}\text { January } 1999 \text { - } \\
\text { March } 2004\end{array}$ & $\begin{array}{l}\text { Matching } \\
\text { Methods }\end{array}$ & $\begin{array}{l}\text { - Effective during } 1999 \text { - } 2002 \text { sub- } \\
\text { sample when intervention was } \\
\text { infrequent ( } 3 \% \text { of business days) } \\
\text { - No significant effect during } 2003 \text { sub- } \\
\text { sample when intervention was more } \\
\text { frequent ( } 35 \% \text { of business days) } \\
\text { - Ineffective during } 1^{\text {st }} \mathrm{Q} 2004 \text { sub- } \\
\text { sample when intervention was } \\
\text { extremely frequent ( } 85 \% \text { of business } \\
\text { days) }\end{array}$ \\
\hline Ito (2003) & $\begin{array}{l}\text { April } 1991- \\
\text { March } 2001\end{array}$ & $\begin{array}{l}\text { Time-series } \\
\text { GARCH(1,1) }\end{array}$ & $\begin{array}{l}\text { - More frequent and more predictable in } \\
\text { April } 1991 \text { - } 20 \text { June } 1995 \text { sub-sample } \\
\text { - Ineffective during April } 1991 \text { - } \\
\text { 20 June } 1995 \text { sub-sample } \\
\text { - Effective during } 21 \text { June } 1995 \text { - } \\
\text { March } 2001 \text { sub-sample } \\
\text { - More effective when coordinated } \\
\text { (both Fed and BOJ) }\end{array}$ \\
\hline Ito (2004) & $\begin{array}{l}\text { January } 2003- \\
\text { March } 2004\end{array}$ & $\begin{array}{l}\text { Time-series } \\
\text { GARCH }(1,1)\end{array}$ & $\begin{array}{l}\text { - Effective during } 2003 \text { - } 2004 \text { sample } \\
\text { - Initial intervention operations more } \\
\text { effective than subsequent ones } \\
\text { - Degree of impact smaller than during } \\
1995 \text { - } 2003 \text { sub-sample }\end{array}$ \\
\hline
\end{tabular}


Table 4. Matching Methods: January 1999 - March 2004.

Intervention in terms of USD purchases $=>$ Expect positive sign

\begin{tabular}{cllllll}
\hline & \multicolumn{1}{c}{ All } & $\begin{array}{c}\text { Clusters All } \\
\text { (CLALL) }\end{array}$ & $\begin{array}{l}\text { Clusters } \\
\text { Middle } \\
\text { Day (MD) }\end{array}$ & $\begin{array}{c}\text { Clusters } \\
\text { Last Day } \\
\text { (LD) }\end{array}$ & SA and FD \\
\hline \multirow{2}{*}{$1999-2002$} & $\begin{array}{l}0.005110^{* *} \\
(2.2664)\end{array}$ & $\begin{array}{l}0.002588 \\
(1.0027)\end{array}$ & n.a. & $\begin{array}{l}0.001322 \\
(0.4410)\end{array}$ & $\begin{array}{l}0.004896^{*} \\
(1.6075)\end{array}$ \\
& & & & & \\
2003 & 0.000179 & 0.000085 & -0.000234 & 0.001028 & 0.000315 \\
& $(0.2397)$ & $(0.1102)$ & $(-0.2320)$ & $(0.7025)$ & $(0.1099)$ \\
2004 Q1 & $-0.001340^{*}$ & $-0.001340^{*}$ & -0.000994 & -0.002178 & $-0.003055^{* *}$ \\
& $(-1.5707)$ & $(-1.5707)$ & $(-1.1189)$ & $(-0.6437)$ & $(-2.0842)$ \\
& & & & & & \\
\hline
\end{tabular}

Source: Fatum and Hutchison (2004) 
Table 5. The Bank of Japan Current Account and Intervention: Daily Data ${ }^{a}$

\begin{tabular}{lcccc}
\hline \multicolumn{4}{c}{ Dependent variable: The Bank of Japan Current } & Account (first-differences) \\
\hline & $(1)$ & $(2)$ & $(3)$ & $(4)$ \\
& 36.85 & 34.04 & 190.34 & 107.18 \\
Constant & $(63.35)$ & $(58.97)$ & $(255.96)$ & $(220.16)$ \\
& 0.59 & 0.58 & 0.30 & 0.42 \\
Intervention & $(0.57)$ & $(0.57)$ & $(0.31)$ & $(0.27)$ \\
& -0.68 & -0.67 & $-1.05^{* * *}$ & $-1.17^{* * *}$ \\
Intervention(-1) & $(0.49)$ & $(0.48)$ & $(0.37)$ & $(0.35)$ \\
& 0.29 & 0.25 & $1.31^{* * *}$ & $1.27^{* * *}$ \\
Intervention(-2) & $(0.31)$ & $(0.30)$ & $(0.21)$ & $(0.23)$ \\
& 0.00 & -0.05 & $-0.43^{*}$ & $-0.53^{* *}$ \\
Intervention(-3) & $(0.23)$ & $(0.23)$ & $(0.25)$ & $(0.26)$ \\
& -0.17 & & -0.03 & \\
Intervention(-4) & $(0.17)$ & & $(0.32)$ & \\
& -0.01 & & -0.46 & \\
Intervention(-5) & $(0.20)$ & & $(0.30)$ & \\
& 239 & 241 & 60 & 60 \\
Observations & 0.04 & 0.04 & 0.20 & 0.18 \\
$\mathrm{R}^{2}$ & 1.98 & 1.98 & 1.69 & 1.69 \\
Durbin-Watson & 1.54 & $2.23^{*}$ & $2.20^{*}$ & $3.03^{* *}$ \\
F-test of Regression & 0.01 & 0.07 & 0.33 & 0.00 \\
F-test of Sum Equals Zero & 0.003 \\
\hline
\end{tabular}

a) OLS regressions corrected for heteroskedasticity (using White's standard errors). Standard errors in parentheses; $* * *$ denotes significance at the $99 \%$ level, ** denotes significance at the $95 \%$ level, * denotes significance at the $90 \%$ level. 
Table 6. Intervention and the Bank of Japan Current Account: Monthly Data (a)

\begin{tabular}{|c|c|c|}
\hline \\
\hline \multirow{2}{*}{\multicolumn{2}{|c|}{$\begin{array}{l}\text { Part A: } \\
\text { Total Monthly Intervention } \\
\text { (Series } 1 \text { in Figure 4) } \\
\text { Jan-03 }\end{array}$}} & $\begin{array}{l}\text { Monthly Change in Current } \\
\text { (Series } 2 \text { in Figure } 4 \text { ) }\end{array}$ \\
\hline & & 860 \\
\hline Feb-03 & 1061.4 & -200 \\
\hline Mar-03 & 551.8 & 10710 \\
\hline Apr-03 & 0 & -4920 \\
\hline May-03 & 3899.7 & 2930 \\
\hline Jun-03 & 628.9 & -10 \\
\hline Jul-03 & 2027.1 & 320 \\
\hline Aug-03 & 412.4 & -130 \\
\hline Sep-03 & 5111.6 & 5440 \\
\hline Oct-03 & 1668.7 & -4720 \\
\hline Nov-03 & 1587.2 & 1180 \\
\hline Dec-03 & 2619.6 & -990 \\
\hline Jan-04 & 6821.5 & 3940 \\
\hline Feb-04 & 3476.6 & -900 \\
\hline Mar-04 & 4533.2 & 3290 \\
\hline
\end{tabular}

\section{Part B:}

Accumulated Intervention

Jan-Feb 2003

Jan-Mar 2003

Jan-Apr 2003

Jan-May 2003

Jan-Jun 2003

Jan-Jul 2003

Jan-Aug 2003

Jan-Sep 2003

Jan-Oct 2003

Jan-Nov 2003

Jan-Dec 2003

Jan-Mar 2004

Jan 2003 -Mar 2004
1739.5

2291.3

2291.3

6191

6819.9

8847

9259.4

14371

16039.7

17626.9

20246.5

14831.3

35077.8
Accumulated Change in Current Account 660

11370

6450

9380

9370

9690

9560

15000

10280

11460

10470

6330

a) All numbers in billions of JPY. 
Figure 1

JPYIUSD Exchange Rate and

Foreign Exchange Market Intervention

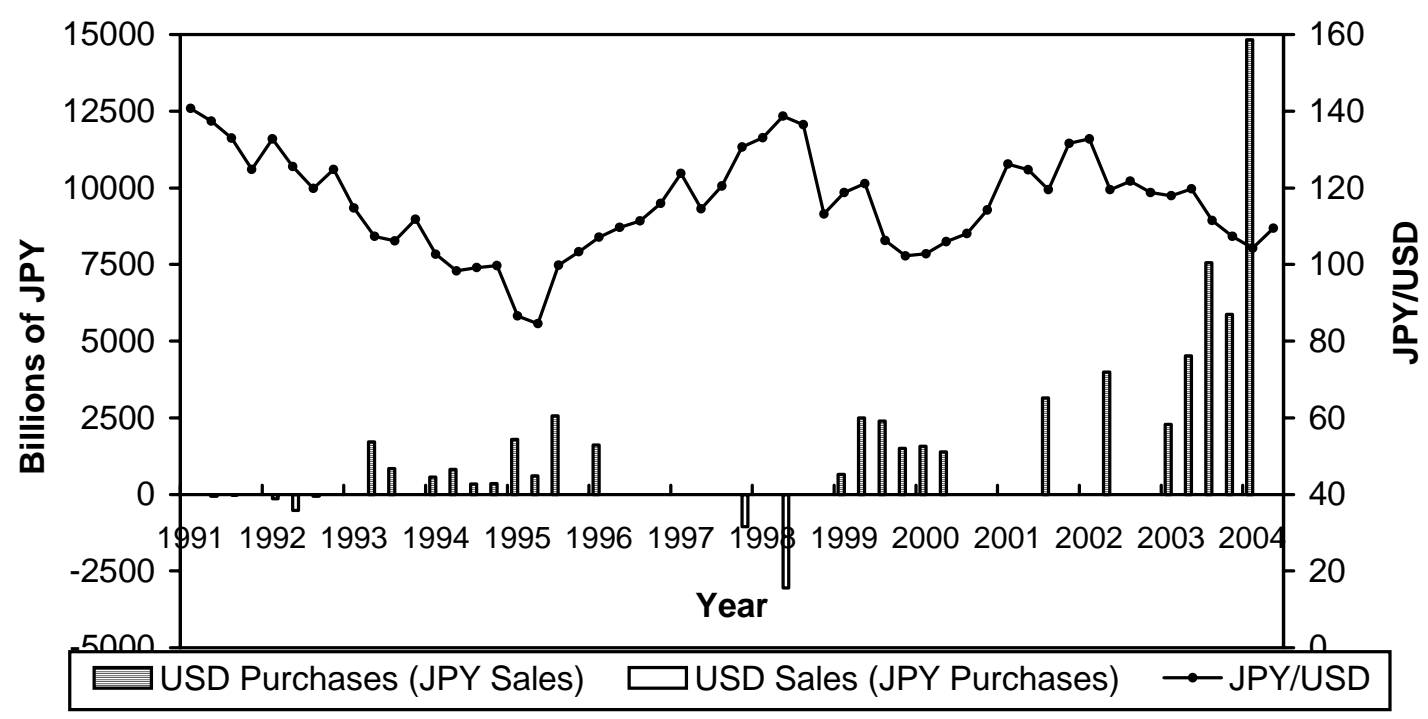

Source: Japanese Ministry of Finance. 


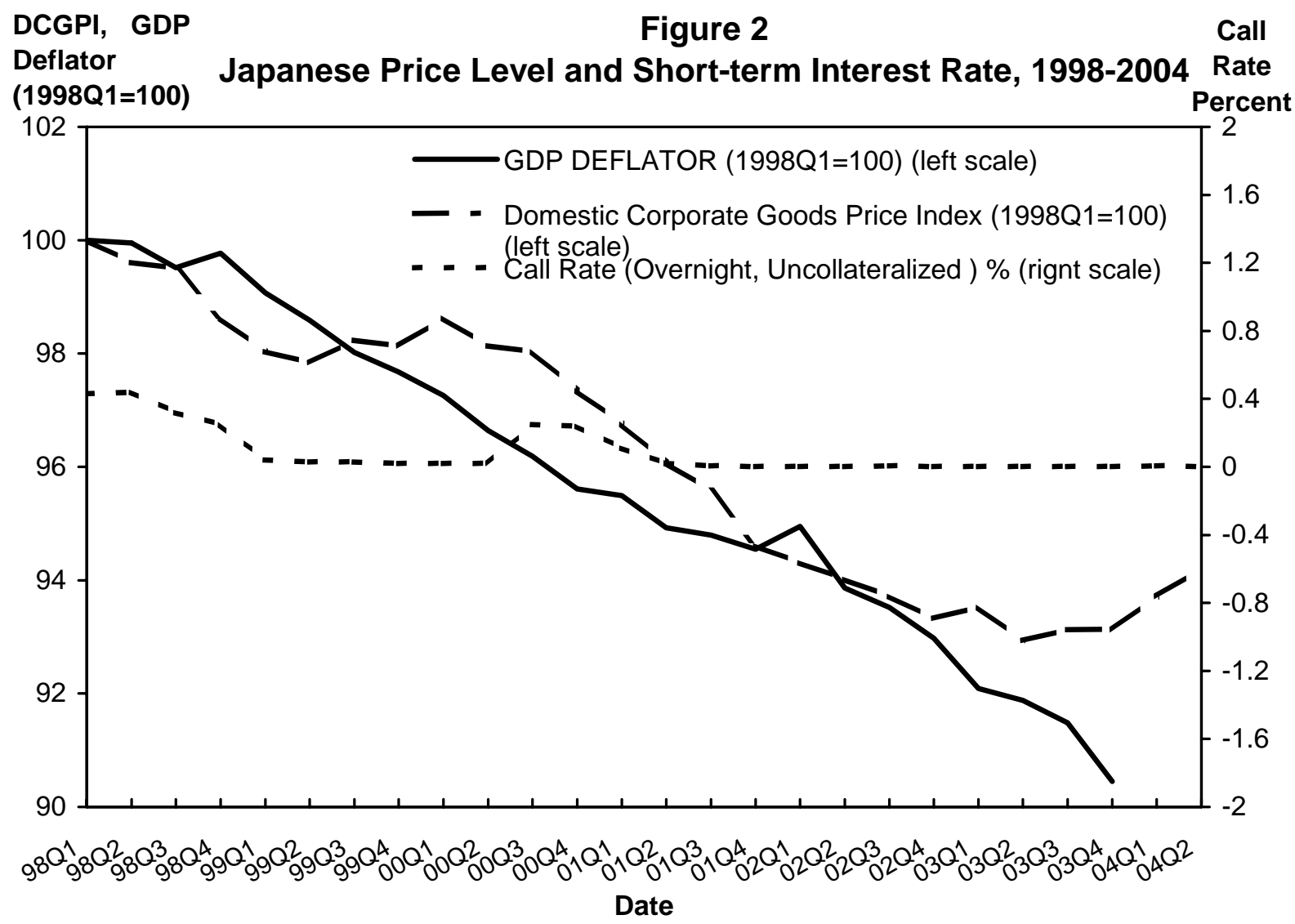

Source: Japanese Ministry of Finance. 
Figure 3

Monetary Base Increase and JPYIUSD Intervention

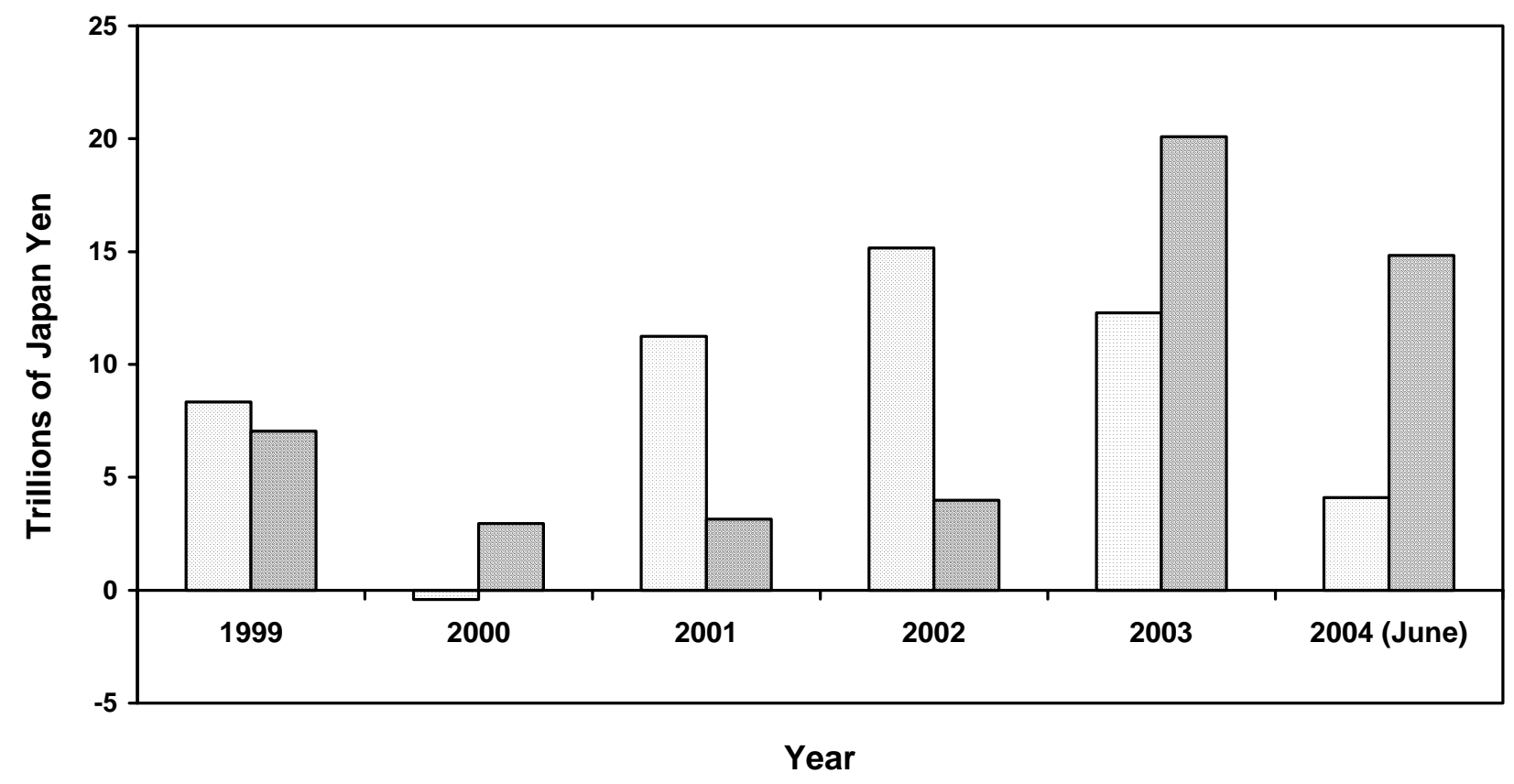

$\square$ Change of Monetary Base $\quad \square$ Purchases of US Dollars (in trillions of JPY)

Source: Japanese Ministry of Finance. 


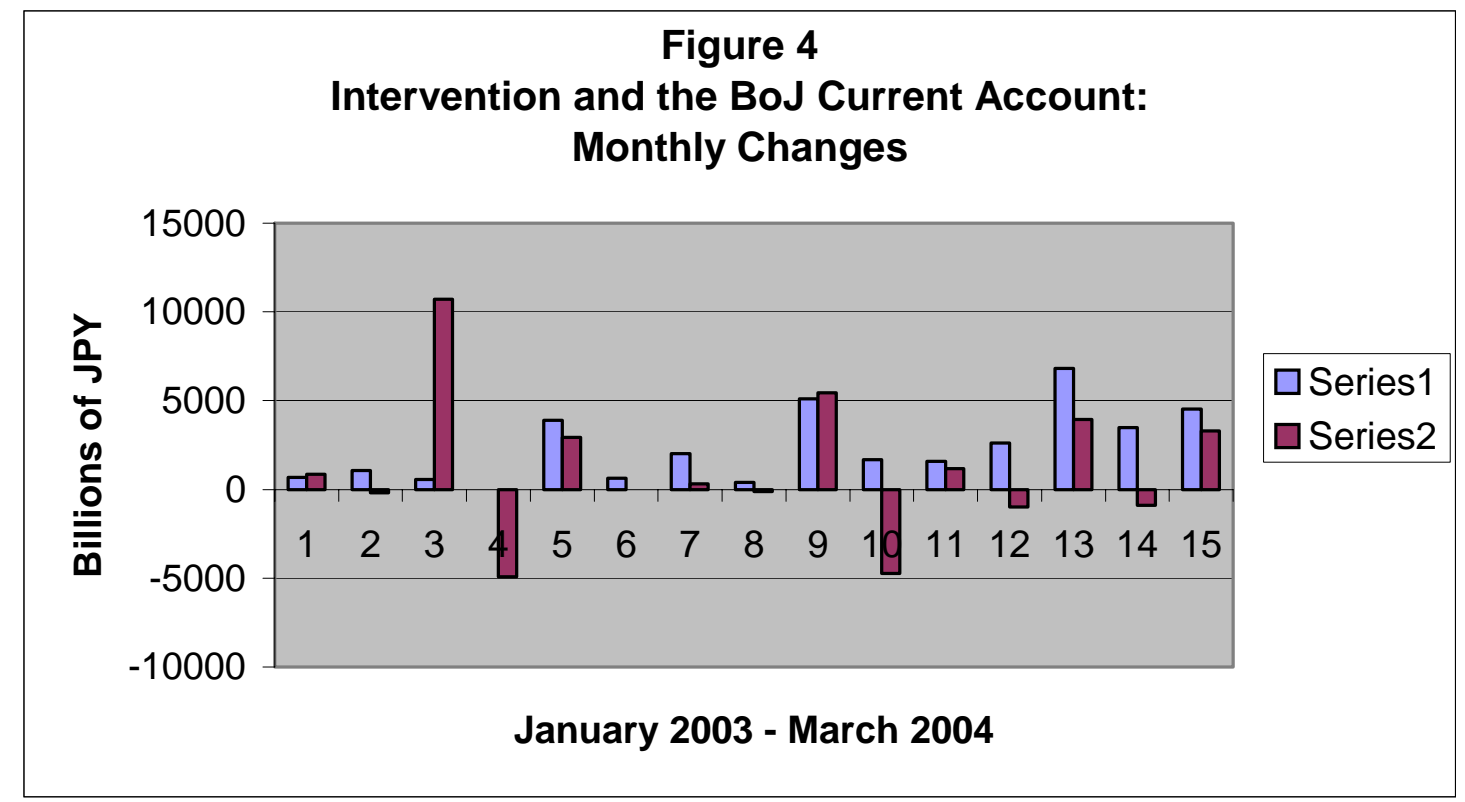

Source: Japanese Ministry of Finance. 
Figure 5

a. Japan's Money Base and BOJ Intervention, 1993-1996

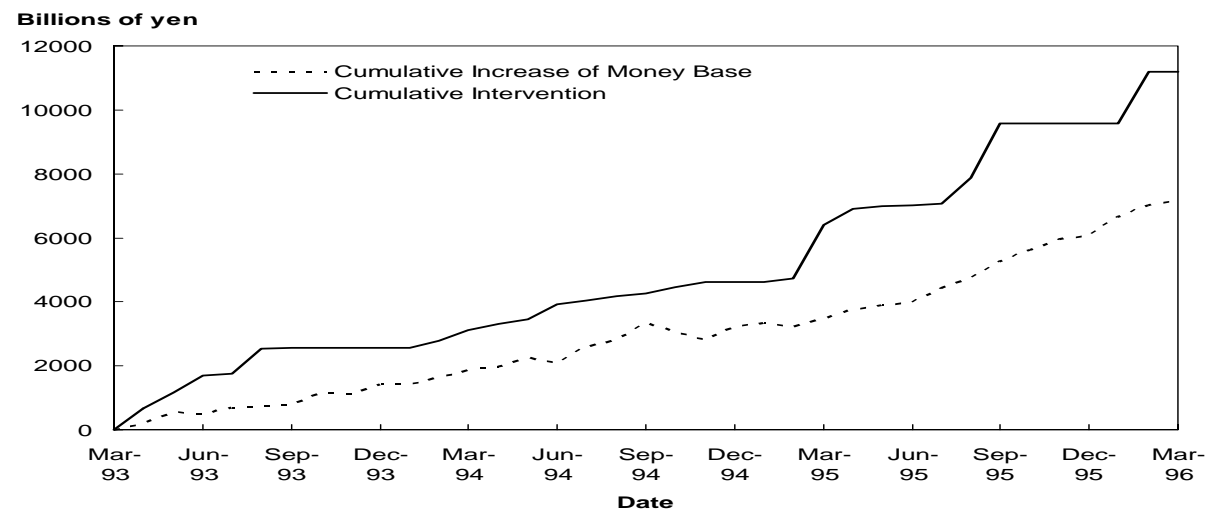

b. Japan's Money Base and BOJ Intervention, 1999-2000

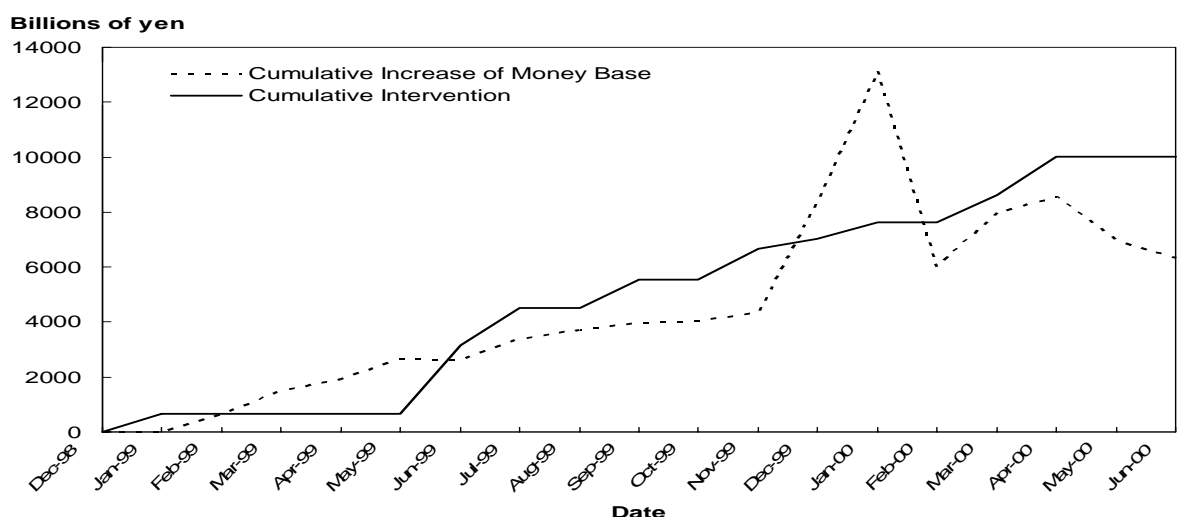

c. Japan's Money Base and BOJ Intervention, 2003-2004

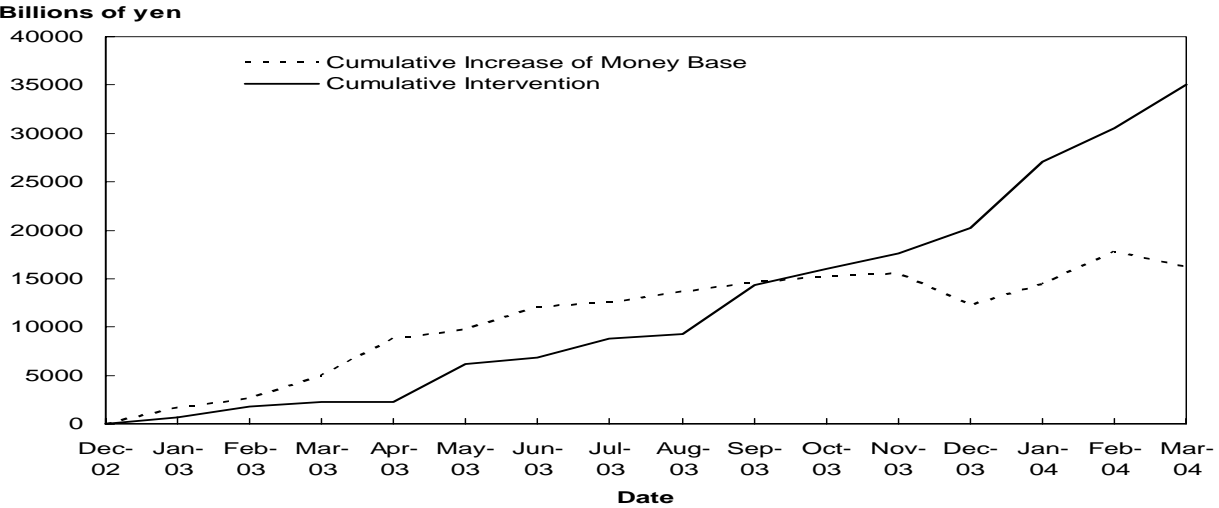


Figure 6

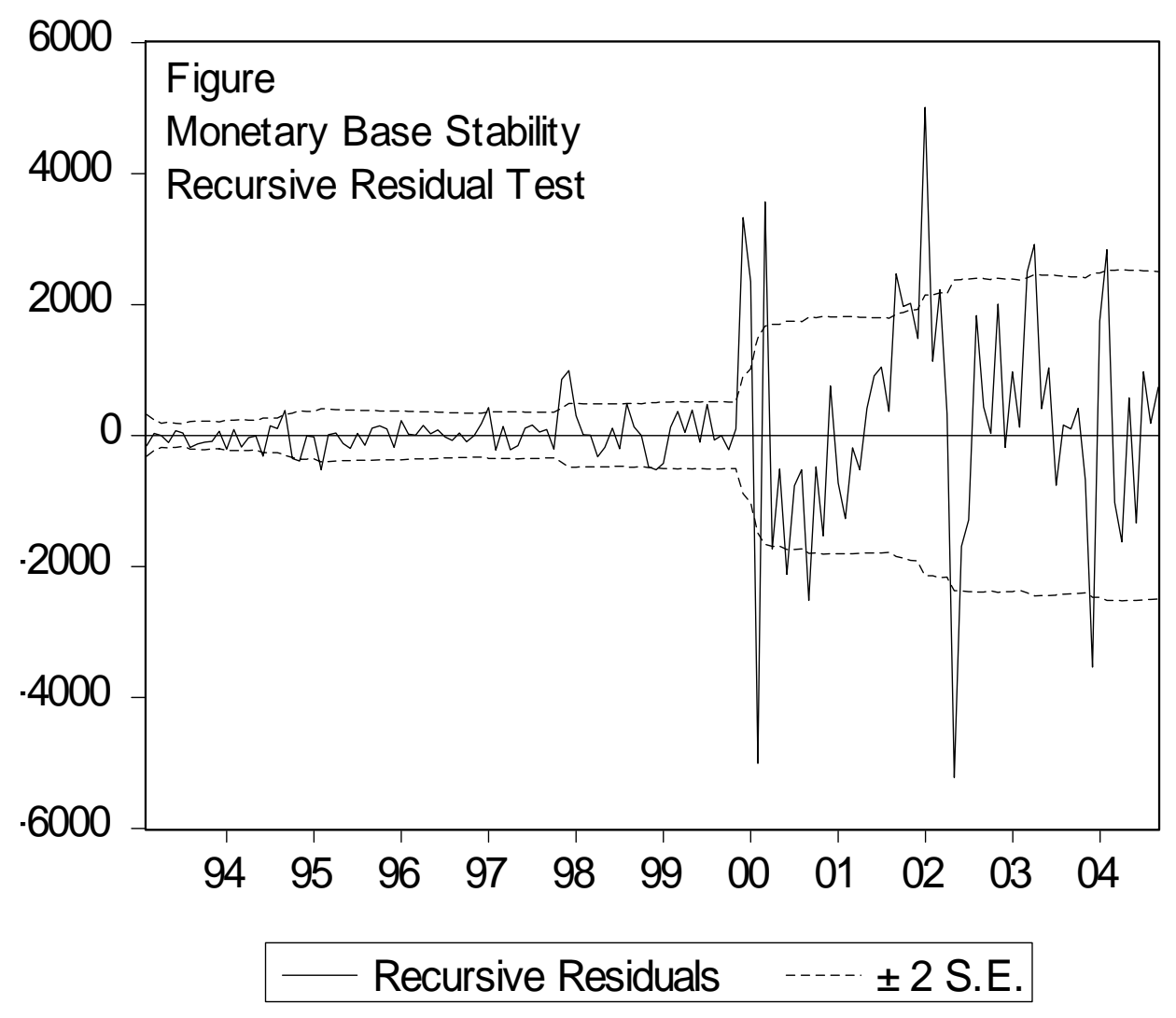


Figure 7

Bank of Japan's Money Base Increase

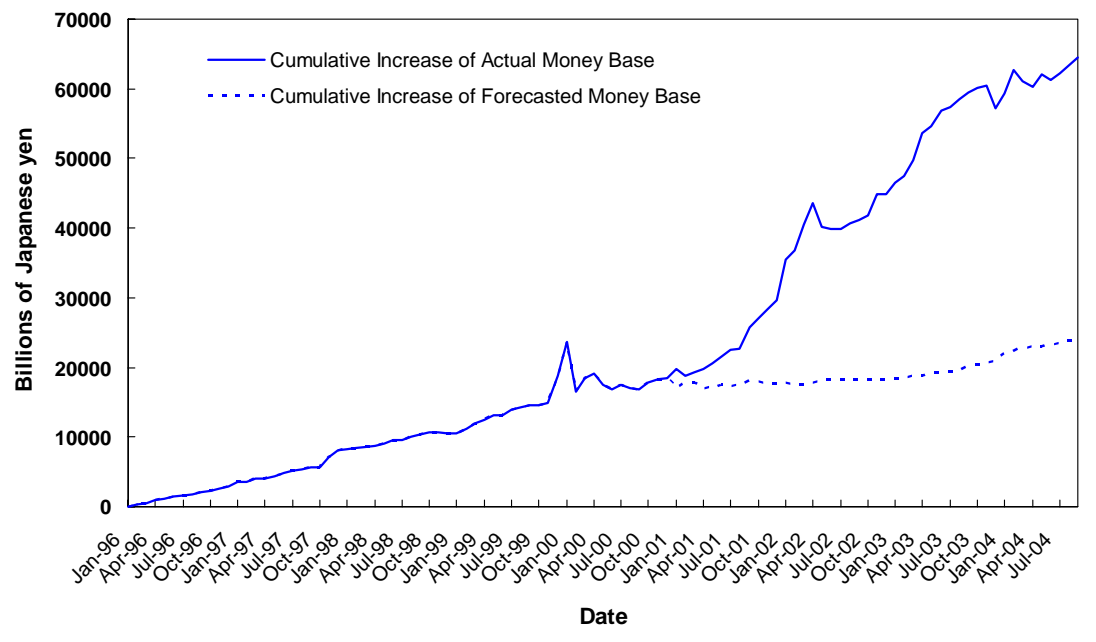

Note: The forecast begins from January 2001, based on the data from January 1991 to December 2000. 
Figure 8

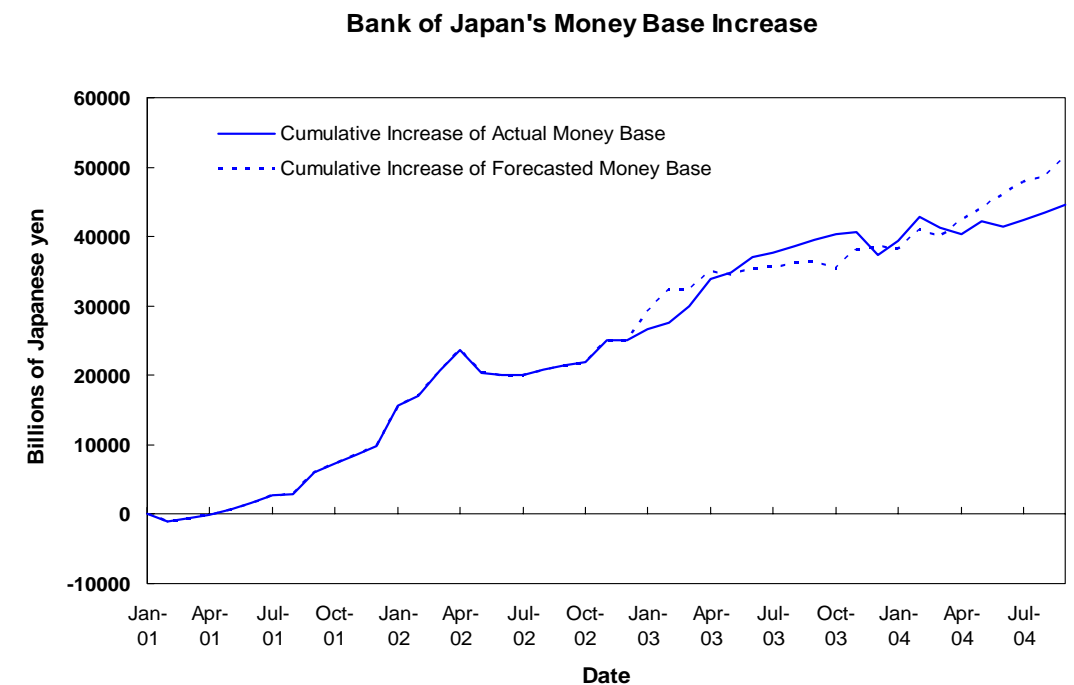

Note: The forecast begins from January 2003, based on the data from January 2001 to December 2002 